\title{
COMPOSITION OF GASES IN INTERCELLULAR SPACES OF APPLES AND POTATOES
}

\section{CONTRIBUTIONS FROM THE HULL BOTANICAL LABORATORY 271}

J. R. MAGNESS

(WITH ONE FIGURE)

\section{Introduction}

During a study of the ripening processes in fruits, and the chemical and physiological changes associated with them, the question has arisen as to what may be the composition of the gas in the intercellular spaces. The gas within the tissues constitutes in part the medium in which the processes associated with the life of an organism take place. It is only reasonable to suppose that the composition of this medium may exert some influence upon the rate or nature of the changes taking place. The difficulty of extracting the gases from the interior of the tissues is probably responsible for the fact that plant physiologists have almost entirely neglected studies along this line. GERBER (5) reports work of FrEMY published in I840 and I860, in which the gas contained in apples was analyzed at intervals during their development and ripening. He found oxygen more abundant in the green fruit, the amount decreasing as the fruit matured on the tree. We have, however, no critical studies upon the internal gases of plant tissues.

An apparatus has been devised for obtaining a sample of the gas from within the tissues, without contamination with air. It is the purpose of this preliminary report to describe the apparatus and methods of sampling, together with the data secured, in order that they may be available to workers along related lines.

\section{Apparatus}

The apparatus used in extracting the gas is shown in fig. I. It consists of a leveling bottle or burette $(A)$, connected through heavy walled rubber tubing to a side neck at the base of a thickwalled glass cylinder $(B)$. This cylinder is flared at the top, and 
fitted with a ground glass stopper $(C)$ in which is sealed a capillary tube. The flare in the top of the cylinder should be sufficient to allow the stopper to set well down (as illustrated), in order to permit a mercury seal above the

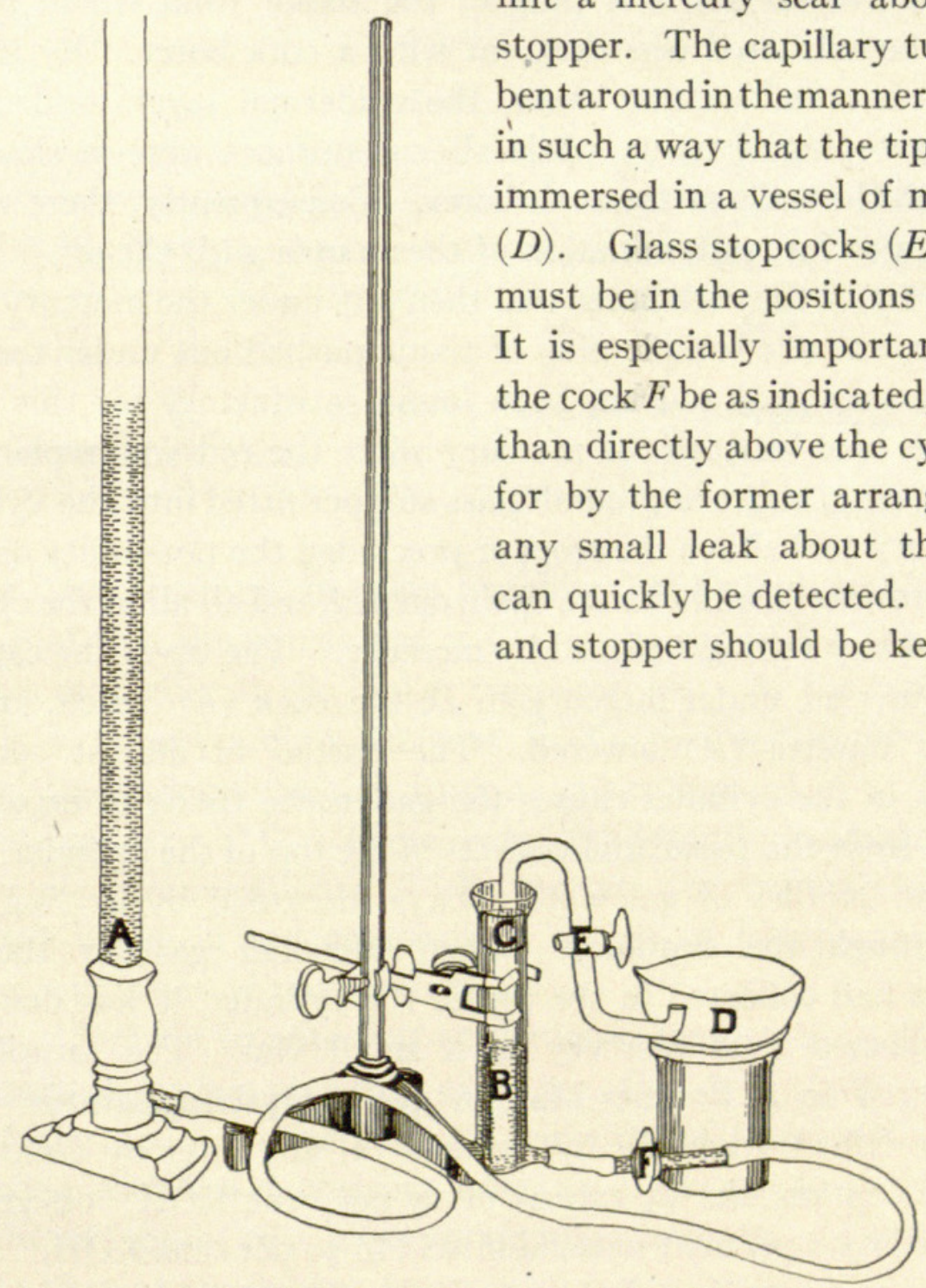

FIG, I

coated with heavy desiccator grease. The proper dimensions for the cylinder $(B)$ will obviously vary with the type of tissue being examined, and the volume of this tissue necessary to secure a gas sample adequate for an analysis. For work with apple and potato tissue, a cylinder 6 inches long and $\mathrm{I}$ inch inside diameter has been found very satisfactory. 


\section{Method}

By opening the stopcock $E$ and $F$, mercury was allowed to flow from the leveling burette into the cylinder until the latter was about two-thirds full. A plug of the tissue from which the gas was to be extracted was then cut with a cork borer. By using a sharp borer and cutting clean, the epidermal layers sealed each end of the plug of tissue, while all cut surfaces were in close contact with the walls of the cork borer. Consequently, there was no opportunity for contamination of the sample with the air.

The tip of the cork borer was then put under the mercury in the cylinder, and the sample plug of tissue pushed out under the mercury; a long glass rod has been found satisfactory for this. The plug was held beneath the mercury while the rod was replaced by a wire spring, and the ground glass stopper fitted into the cylinder. A mercury seal above the stopper precluded the possibility of leaks. The stopcocks $(E$ and $F)$ were again opened, and all air in the cylinder and capillary tubing replaced by mercury. The tip of the capillary was immersed under mercury in $D$, the cock $(E)$ closed, and the leveling burette $(A)$ lowered. The partial or almost complete vacuum in the cylinder causes the gas in the tissue to expand; it escapes from the tissue and collects in the top of the cylinder. The first few bubbles of gas were always discarded by driving them out through the capillary. When sufficient gas for the final analysis had collected in the top of the cylinder, it was driven off and collected over mercury in a small vial. The sample was transferred to a Bonnier-Mangin gas analysis apparatus of the type described originally by Aubert (2) and later by Grafe (4). $\mathrm{CO}_{2}$ absorption was by means of $\mathrm{I}_{5}$ per cent $\mathrm{KOH}$; oxygen was absorbed by 8 per cent pyrogallic acid in 30 per cent $\mathrm{KOH}$. About one-half cc. of gas is sufficient for an analysis in this apparatus.

\section{Results}

Three boxes of Yellow Newton apples, representing three different trees at Watsonville, California, were used in the analyses of gas in apples. Some apples from each box were stored in a refrigerator at $6^{\circ} \mathrm{C}$. and at $\mathrm{II}^{\circ} \mathrm{C}$. Others were stored in a vessel immersed in a water bath held at $20^{\circ} \mathrm{C}$.; while a fourth lot was 
held in an oven at $30^{\circ} \mathrm{C}$. A few were held also at $2^{\circ} \mathrm{C}$. In all cases abundant aeration was provided to prevent the possibility of an accumulation of $\mathrm{CO}_{2}$ in the air surrounding the fruit. A summary of the data on the internal atmospheres in apples is given in table I.

TABLE I

Analyses of gas in intercellular spaces of Yellow Newton apples

\begin{tabular}{|c|c|c|c|c|c|}
\hline $\begin{array}{l}\text { Temperature of } \\
\text { storage }{ }^{\circ} \mathrm{C} \text {. }\end{array}$ & $\begin{array}{l}\text { Number of } \\
\text { determinations }\end{array}$ & Percentage $\mathrm{CO}_{2}$ & Percentage $\mathrm{O}_{2}$ & $\begin{array}{c}\text { Percentage } \\
\mathrm{CO}_{2}+\mathrm{O}_{2}\end{array}$ & $\begin{array}{l}\text { Percentage } \mathrm{N}_{2} \\
\text { by difference }\end{array}$ \\
\hline $\begin{array}{l}2 \ldots \ldots \ldots \ldots \\
6 \ldots \ldots \ldots \ldots\end{array}$ & $\begin{array}{r}5 \\
30\end{array}$ & $\begin{array}{l}6.7 \\
8.4\end{array}$ & $\begin{array}{l}\text { I } 4.2 \\
\text { I } 2.0\end{array}$ & 20.9 & $79 \cdot 1$ \\
\hline II.......... & 27 & $\begin{array}{r}12.4 \\
12.2\end{array}$ & $\begin{array}{l}12.9 \\
10.7\end{array}$ & $\begin{array}{l}21.3 \\
22.9\end{array}$ & $\begin{array}{l}78.7 \\
77.1\end{array}$ \\
\hline $20 \ldots \ldots \ldots$. & $3 I$ & 17.2 & $5 \cdot 5$ & 22.7 & $77 \cdot 3$ \\
\hline $30 \ldots \ldots \ldots \ldots$ & 29 & $2 \mathrm{I} \cdot 4$ & 3.2 & 24.6 & $75 \cdot 4$ \\
\hline
\end{tabular}

The data presented in table I require but little discussion. It is apparent that the percentage of $\mathrm{CO}_{2}$ in the gas within the tissues increases markedly at the higher temperatures. At the same time there is a corresponding decrease in the percentage of oxygen present, the average ranging from 14.2 per cent at $2^{\circ} \mathrm{C}$. to only 3.2 per cent at $30^{\circ} \mathrm{C}$. These data, representing averages of a number of determinations, clearly indicate the marked variation that may occur in the composition of gas in the tissues under varying conditions of temperature.

It is of interest to note that at the lower temperatures the total percentage of oxygen plus that of carbon dioxide is about equal to that of the air. At the higher temperatures, however, and in association with the decreasing amounts of oxygen in the tissues, the sum of these two gases gradually increases. This would indicate that at the higher temperatures one molecule of oxygen liberates more than one molecule of $\mathrm{CO}_{2}$. Such data accord with the work of GERBER (5), who found that in fleshy fruits stored at high temperatures acids were mainly respired, and that the ratio of $\mathrm{CO}_{2}$ to $\mathrm{O}_{2}$ under these conditions was considerably superior to unity. There is also the possibility that at the higher temperatures a certain amount of anaerobic respiration is going on, due to the relatively small amount of oxygen present. This would result in 
an increased amount of $\mathrm{CO}_{2}$ in the tissues, without a corresponding decrease in oxygen.

Table II gives the data obtained for potatoes. The potatoes used were purchased on the open market, and the variety was not determined. They were sound, smooth, and of uniform average size. A few carrots were also studied, for comparison with the apples and potatoes. From the data presented it is apparent that the same general tendency holds in potatoes and carrots that was noted in apples, that is, an increasing percentage of $\mathrm{CO}_{2}$ and a decreasing oxygen content at higher temperatures.

TABLE II

ANALYSES OF GAS IN INTERCELLULAR SPACES OF POTATOES AND CARROTS

\begin{tabular}{|c|c|c|c|c|c|}
\hline $\begin{array}{l}\text { Temperature of } \\
\text { storage }{ }^{\circ} \mathrm{C} \text {. }\end{array}$ & $\begin{array}{c}\text { Number of } \\
\text { determinations }\end{array}$ & Percentage $\mathrm{CO}_{2}$ & Percentage $\mathrm{O}_{2}$ & $\begin{array}{c}\text { Percentage } \\
\mathrm{CO}_{2}+\mathrm{O}_{2}\end{array}$ & $\begin{array}{l}\text { Percentage } \mathrm{N}_{2} \\
\text { by difference }\end{array}$ \\
\hline \multirow{3}{*}{$\begin{array}{l}\text { Ir } \ldots \ldots \ldots \ldots \\
22 \ldots \ldots \ldots \ldots\end{array}$} & \multicolumn{5}{|c|}{ Potatoes } \\
\hline & $\begin{array}{l}8 \\
8\end{array}$ & $\begin{array}{l}19.6 \\
34.4\end{array}$ & $\begin{array}{r}10.9 \\
5.7\end{array}$ & $\begin{array}{l}30.5 \\
40.1\end{array}$ & $\begin{array}{l}69 \cdot 5 \\
59 \cdot 9\end{array}$ \\
\hline & \multicolumn{5}{|c|}{ Carrots } \\
\hline $\begin{array}{l}\text { I } 1 \ldots \ldots \cdots \\
24 \ldots \ldots \ldots\end{array}$ & $\begin{array}{l}2 \\
2\end{array}$ & $\begin{array}{l}12.2 \\
28.6\end{array}$ & $\begin{array}{r}13 . I \\
5.2\end{array}$ & $\begin{array}{l}25 \cdot 3 \\
33.8\end{array}$ & $\begin{array}{l}76.7 \\
66.2\end{array}$ \\
\hline
\end{tabular}

It will be noted that the total $\mathrm{CO}_{2}$ and oxygen is much higher in the case of potatoes than was found in apples. This variation may be due in part to the fact that there is relatively much less intercellular space in potatoes than in apples, and a higher percentage of the gas may have come out of solution in the juice in the samples obtained from potatoes than in those obtained from apples. It is necessary to use much larger samples of potato tissue in order to obtain sufficient gas for an analysis than is essential when apple tissue is used.

The amount of gas that may be coming out of solution in the juice, rather than from the intercellular spaces, presents a difficulty inherent in this method of sampling. There is no assurance that the gas that comes out of solution is of exactly the same composition as that of the intercellular spaces. The consistent results recorded 
for fruit under the different temperatures tested, however, clearly indicate the tendency of the oxygen-carbon dioxide ratio within the tissues, regardless of the fact that the absolute values may vary somewhat.

\section{Effect of wounding}

Many references to the effect of wounding plant tissues upon rate of respiration are found in the literature. Invariably wounding of the tissue has resulted in an increased rate of respiration. GERBER has found this to be true of apples, grapes, and other fruits. Appleman (I) has reported the same phenomenon for white potatoes.

A few apples were prepared for a study of the effect of wounding upon the composition of the internal atmosphere. A thin slice of the peel was removed from each end of the fruits, and they were then put in storage at the various temperatures by the side of whole fruits serving as checks. The data from the analyses of these fruits are reported in table III. It is apparent from these data that removing the epidermis greatly facilitates the entrance of oxygen to the tissues, and also the escape of accumulated $\mathrm{CO}_{2}$. It would be interesting to know to what extent increased respiration following wounding is due to mechanically facilitating this gaseous exchange, and to what extent it is due to actual metabolic changes in the wounded tissues.

\section{TABLE III}

EFFECT OF REMOVING PEEL FROM ENDS OF FRUITS UPON COMPOSITION OF INTERNAL ATMOSPHERE

\begin{tabular}{|c|c|c|c|c|c|}
\hline $\begin{array}{l}\text { Tempera- } \\
\text { ture }{ }^{\circ} \mathrm{C} \text {. }\end{array}$ & Treatment & $\begin{array}{c}\text { Number of } \\
\text { Determinations }\end{array}$ & Percentage $\mathrm{CO}_{2}$ & Percentage $\mathrm{O}_{2}$ & $\begin{array}{c}\text { Percentage } \mathrm{CO}_{2} \\
+\mathrm{O}_{2}\end{array}$ \\
\hline $\begin{array}{r}1 \ldots \ldots \\
1 \ldots \ldots \ldots \\
20 \ldots \ldots \\
20 \ldots \ldots \\
30 \ldots \ldots \\
30 \ldots \ldots\end{array}$ & $\begin{array}{l}\text { Whole apples } \\
\text { Ends peeled } \\
\text { Whole apples } \\
\text { Ends peeled } \\
\text { Whole apples } \\
\text { Ends peeled }\end{array}$ & $\begin{array}{l}3 \\
4 \\
2 \\
2 \\
2 \\
2\end{array}$ & $\begin{array}{r}6.6 \\
1.7 \\
\text { I } 7.8 \\
7.4 \\
23.9 \\
\text { I } 2.6\end{array}$ & $\begin{array}{r}\text { I4.6 } \\
\text { I } 5.8 \\
7.0 \\
9.9 \\
1.8 \\
8.9\end{array}$ & $\begin{array}{l}21.2 \\
17.5 \\
24.8 \\
17.3 \\
25.7 \\
21.5\end{array}$ \\
\hline
\end{tabular}

\section{Variation in composition of gases}

Considerable variation occurred between individual apples or potatoes held under identical conditions. This is to be expected 
when the wide variation in size, thickness of epidermis, etc., is considered. The extremes of variation found in apples held at $20^{\circ} \mathrm{C}$. are indicative of the range of fluctuation that may be encountered in work of this type. The $3 \mathrm{I}$ apples analyzed at this temperature contained gas averaging $\mathrm{I} 7.2$ per cent $\mathrm{CO}_{2}$. The minimum $\mathrm{CO}_{2}$ recorded for any apple of the lot was I 2.5 per cent; the maximum 25.7 per cent. Only one apple, however, showed more than $2 \mathrm{I} .8$ per cent, so that this latter figure is a more accurate maximum. The extremes of oxygen variation were somewhat less. With an average of 5.5 per cent oxygen, the minimum value was I.O per cent, and the maximum 9.5 per cent. Although most of the values were very much nearer the mean than these, it is essential that a considerable number of individual analyses be made to determine the true mean for any given condition.

\section{Factors influencing amount}

Three main factors operate to determine the amounts of $\mathrm{CO}_{2}$ and oxygen in the intercellular spaces at any given temperature. These are (I) the rate of oxidation, or the rate at which oxygen is taken up from and $\mathrm{CO}_{2}$ given off into the intercellular spaces; (2) the permeability of the skin or epidermal covering to $\mathrm{CO}_{2}$ and oxygen; and (3) the difference in pressure of $\mathrm{CO}_{2}$ and oxygen within and without the fruit, which determines the rate of gaseous exchange when the permeability factor is constant. The effect on each of these factors of varying the temperature will explain the variation occurring in the internal atmosphere of the tissues studied at the different temperatures.

EFFECT OF TEMPERATURE ON OXIDATION PROCESSES.-GORE (6) has found that the rate of respiration for a large number of fruits, as measured by the quantity of $\mathrm{CO}_{2}$ given off, increased, on an average, 2.38 times for a $10^{\circ}$ rise in temperature. Enzymatic processes in general, within the range of temperatures here studied, show an increase of from two to three times for each $10^{\circ}$ rise. It is thus apparent that the oxidative processes will be speeded up very markedly by temperature increases.

EFFECT OF TEMPERAture on PERMEABILITy.-DenNy (3), in a study of the permeability of a number of plant membranes, has 
found that in general the increase in permeability per $10^{\circ}$ rise in temperature varies from I. 3 to I. 8 times, averaging about I. 5 . These data are based on permeability to water, but there is no reason for believing that gases would be fundamentally different. The diffusion of gases in all probability is mainly a physical process, and as such is relatively much less affected by temperature changes than the chemical changes involved in oxidation.

From a consideration of these relative effects of temperature on oxidation and on permeability, it is apparent that the absorption of oxygen and release of $\mathrm{CO}_{2}$ are increased much more by a given rise in temperature than is the tendency for oxygen to be supplied to the tissues, and $\mathrm{CO}_{2}$ to be given off from them. Consequently, as the temperature is raised, the amount of oxygen in the tissues becomes less and less, while the $\mathrm{CO}_{2}$ accumulates correspondingly. This continues until the third factor becomes effective, that is, the difference of $\mathrm{CO}_{2}$ and oxygen pressures within and without the fruit becomes so great that equilibrium is again established.

\section{Significance of ratio}

No attempt has been made in this preliminary work to associate the percentages of $\mathrm{CO}_{2}$ and oxygen found with the processes taking place in the fruit. The data presented, however, clearly indicate the necessity of taking this factor into consideration in many types of horticultural and physiological investigations. It should be given attention in studies of the effect of temperature upon the processes in plant tissues, for it is readily apparent that much variation may be caused by the composition of the medium in which these processes are carried on. Of special importance is the application of studies of this type to the questions as to the effect of wounding and various other treatments on the respiratory processes in tissues. Finally, it is of prime importance to know the composition of the internal atmosphere in studying the effects of various gases, etc., on plant organs. Some work has been done on the effect of various gases on fruits and vegetables in storage. Obviously it is essential in such work that the composition of the internal atmosphere be known. 
The writer feels deeply indebted to Dr. William Crocker, and to Mr. W. S. Ballard, U.S. Department of Agriculture, for valuable suggestions in regard to the apparatus for extracting the gas, and for many helpful suggestions during the progress of this work.

\section{U.S. Department of Agriculture Watsonville, Cal.}

\section{LITERATURE CITED}

I. Appleman, C. O., Study of rest period in potato tubers. Md. Agric. Exp. Sta. Bull. no. I83. I9I4.

2. Aubert, E., Nouvel appariel de MM. G. Bonnier et L. Mangin pour l'analyse des gaz. Rev. Gen. Botanique 3: 97-104. I894.

3. Denny, F. E., Permeability of certain plant membranes to water. Вот. GAZ. 63:373-397. I9I7.

4. Grafe, V., Ernahrungsphysiologisches Practicum höherer Pflanzen. p. 377. I9I4.

5. Gerber, C., Recherches sur la maturation des fruits charnus. Ann. Sci. Bot. VIII. 4: I-280. I896.

6. Gore, H. C., Studies on fruit respiration. U.S. Dept. Agric. Bur. Chem. Bull. no. I42. I9II. 


\section{$2 \mathrm{BHL}$ Biodiversity Heritage Library}

Magness, J R . 1920. "Composition of Gases in Intercellular Spaces of Apples and Potatoes." Botanical gazette 70(4), 308-316.

https://doi.org/10.1086/332751.

View This Item Online: https://www.biodiversitylibrary.org/item/109582

DOI: https://doi.org/10.1086/332751

Permalink: https://www.biodiversitylibrary.org/partpdf/224206

\section{Holding Institution}

Missouri Botanical Garden, Peter H. Raven Library

\section{Sponsored by}

Missouri Botanical Garden

\section{Copyright \& Reuse}

Copyright Status: Public domain. The BHL considers that this work is no longer under copyright protection.

This document was created from content at the Biodiversity Heritage Library, the world's largest open access digital library for biodiversity literature and archives. Visit BHL at https://www.biodiversitylibrary.org. 